\title{
THE INFLUENCE OF ORGANIZATIONAL CULTURE ON LEADERSHIP - CASE STUDY MONTENEGRO
}

\author{
Gordana Nikčević
}

Original scientific paper The aim of this paper is to examine the influence of organizational culture on leadership. The assumption that organizational culture affects leadership implies that dominance of different types of cultures in an organization implies different styles of leadership. Empirical research encompassed a sample of 16 companies (423 employees) in Montenegro where respondents answered the survey questions. The analysis of data obtained was conducted by Chi square test. The research findings showed that different types of organizational culture, depending on their content, imply different styles of leadership.

Keywords: company; leadership; Montenegro; organizational culture

Utjecaj organizacijske kulture na liderstvo - analiza slučaja Crna Gora

Izvorni znanstveni članak Cilj ovoga rada je ispitati utjecaj organizacijske kulture na liderstvo. Pretpostavka da organizacijska kultura utječe na liderstvo podrazumijeva da dominacija različitih vrsta kultura u organizaciji implicira različite stilove liderstva. Empirijsko istraživanje obuhvatilo je uzorak od 16poduzeća (423 zaposlenih) u Crnoj Gori koji su odgovorili na pitanja postavljena u istraživanju. Analiza dobivenih podataka je izvršena metodom Hi kvadrat testa (Chi square test). Rezultati istraživanja su pokazali da organizacijska kultura ima izravan i značajan utjecaj na izbor stila liderstva u analiziranim poduzećima tj. da različiti tipovi organizacijske kulture, ovisno od svog sadržaja, imliciraju različite stilove liderstva

Ključne riječi: Crna Gora; liderstvo; organizacijska kultura; poduzeće

\section{Introduction}

Organizational culture includes a system of assumptions, values, norms and attitudes manifested through symbols, developed and adopted by members of an organization through their shared experience which helps them to determine the meaning of their surrounding environment and how to behave in the same. This definition of organizational culture has three very important features significant for its understanding. First, organizational culture includes collective cognitive structures such as assumptions, values, norms and attitudes, but also the symbols through which its cognitive contents are materialized and manifested. Second, organizational culture represents the result of shared experience of members of an organization in solving problems they face in external adaptation to the environmental internal integration of the collective. By solving these problems, successful solutions are being generalized, systematized and pushed into the subconscious from where they guide the behaviour of members of an organization. Third, collective cognitive structures that comprise the organizational culture's content represent a framework and guide to organization's members in interpretation of reality and the world around them. Culture helps members of an organization to determine the meaning of concepts, things and events within the organization as well as out of it and to make decisions and take actions accordingly. Members of an organization behave in it in accordance with interpretations of reality: make decisions, take actions and interact with each other [19].

Organizational culture affects decisions and actions of managers and employees thus afffecting almost all elements of management and organization. In that sense, we have empirical evidence showing how culture affects strategy $[16,23,4]$, performance control [10], organizational structure [18], compensation system [22], performance appraisal [15], organizational leaning [1, 8], as well as organizational performance [21]. One of elements of organizational behavior proven to be influenced by organizational culture is the leadership $[12,6]$.

It is believed that leadership is the most researched issue in the field of organizational behaviour. The relationship between leadership and organizational culture has aroused the greatest interest and initiated a number of researches, but also the controversies. This relationship is particularly interesting and important because of its bidirectional character $[19,2]$. Neither component of organizational behaviour with which organizational culture has a causal relationship shows in such extent that these relationships are of bi-directional character as in this case. What is particularly interesting is that it is very difficult to determine what the independent is and what is the dependent component in this relationship? In this sense, it is very difficult to answer the question whether organizational culture is determined by the leader and his leadership style or whether the leader determines and shapes the culture. Namely, these are two views of the same relation, but from two different perspectives of organizational culture: structural functionalism and interpretivism $[17,2]$. According to structural functionalism perspective the organization has a culture treated as an object of management action to achieve optimum outcomes. In this perspective, the leader shapes the culture in a way that leadership is "older" than culture. In the perspective of interpretivism, organization is culture since everything in the organization is a manifestation of its culture. In this perspective, culture is "older" than leadership so that leadership is just one of the manifestations or symbols of the culture in which it occurs. Given that it is about two different standpoints that start from completely opposite assumptions it is difficult to find a compromise answer. However, there are 
far more studies in which organizational culture is taught from the perspective of structural functionalism, so the number of papers in which the leader shapes the culture is significantly greater than the number of papers in which the culture shapes the leader. In this sense, there is a small number of theoretical explanations of influence of organizational culture on leadership in organizations and therefore the empirical studies to prove this influence. Therefore, the aim of this paper is to provide a theoretical explanation of the mechanism through which organizational culture shapes the leader and his style, as well as, based on this explanation, to place hypotheses about the influence of culture on leadership, which could be empirically tested.

In this paper the first developed will be theoretical framework which will explain and operationalize two main variables of this research: organizational culture and leadership and stated hypotheses about the relationship between organizational culture and leadership. In the next section of the paper the research methodology will be presented: sample, instruments and research methods. Then, through presented research findings the way in which organizational culture influences leadership style will be presented. The research findings are given at the end of this paper, as well as some methodological and theoretical limitations of the same.

\section{Theoretical framework}

Operationalization of organizational culture influence on forming leadership in an organization is possible in certain types of organizational culture and specific leadership styles are brought into a causal relationship. To achieve this, it is necessary to identify the basic criteria and dimensions of organizational culture relevant for shaping the style of the leader and to identify the types of organizational culture according to these dimensions. Then, it is necessary to identify the basic dimensions or criteria according to which leadership styles are differentiated and identify main types of styles according to these criteria. Finally, we should set up hypothesis about the relationship between certain types of organizational cultures on the one hand and leadership styles they imply, on the other hand.

There are numerous classifications of organizational cultures in the literature $[7,5,11,20,9,13,14]$. All these classifications differ from each other according to the criteria based on which organizational cultures are differentiated: external vs. internal focus and flexibility vs. stability $[7,11]$, needs and orientation of the people [5], level of risk and speed of market feedback [9], egalitarity vs. hierarchy in distribution of power and orientation to people vs. orientation to task [20,13]. For exploring the influence of organizational culture on leadership the classification of culture is made according to dimensions of influence that can be associated with it. These are classifications of leadership styles according to degree of involvement of employees in decision-making processes and manners of solving organizational problems [3] as well as Handy's [13, 14] and Trompenaars's classifications [20] that used the same dimensions: norms related to distribution of power and norms related to people or taks. For the purposes of this research we will use Handy's classification of organizational culture, since the questionnaire he constructed was available to the author.

According to Handy's classification (1983, 1979) organizational cultures differentiate according to two criteria. The first criterion are values and norms concerning distribution of power in an organization. According to this criterion there are cultures in which unequal distribution of power is present and cultures that favor equal, i.e. egalitarian distribution of power in organizations. Another criterion for differentiation of organizational culture relates to the primary component of an organization. Every organization consists of labor and social component or tasks and people. Organizational cultures differ according to which component organizations favour as the primary one. In this regard, we distinguish between cultures which by their values and norms favour orientation to people and cultures which by their values and norms favour orientation to tasks. Using both criteria at the same time, a matrix with four types of organizational cultures can be constructed.

Power culture combines orientation to people with unequal distribution of power. This culture is oriented to the leader, which is its main characteristic. Metaphor for this organization is family and the leader is, naturally "the father of the family" who takes care of all its members, and they in turn show unquestioning obedience. The leader personalizes the work of an organization to a large extent so everthing in it gets his personal touch and depends on his style and competences. The organization is informal and the relationships among its members are very close.

Role culture combines orientation to tasks with unequal distribution of power. It is a bureaucratic culture in which the organization represents a regulated social system governed by formal rules and procedures. Metaphor for organization in this culture is a machine. Role culture is depersonalized so the basic elements of an organization are impersonally set roles and not individuals as persons.

Task culture combines orientation to tasks but also egalitarian distribution of power. In this culture, everything is directed and subordinated to solving tasks in an organization thus the organization exists in order to solve tasks. Everything is oriented towards the work that needs to be done and everything is subordinated to it.This culture highly values success and results. Values such as autonomy, competence, development and flexibility rule in the task culture.

People culture combines orientation to people and egalitarian distribution of power. People culture is an individualistic culture. People culture is based on the assumption that the organization exists only to enable its members to achieve their individual goals and interests. Its main purpose, according to its members' assumptions, is to enable them to achieve their individual goals and interests. The power in people culture is very widely distributed so, compared to all of the above mentioned types of culture, people culture is "democratic" to the fullest extent.

As regards leadership operationalization, the two most commonly used criteria or dimensions by which 
different styles of leadership are differentiated are: authoritarianism of the leader, i.e. level of participation of followers in decision-making and orientation to people or tasks in solving organizational problems [3]. Therefore, leaders differ to the extent to which they are independent in decision-making or the extent to which they allow participation of employees in decision-making, as well as according to whether they achieve goals of the organization through formal components, structures, roles, procedures, and tasks or through informal components, relationships, influence to people, etc. Given that there are two dimensions of leadership style, two sexes each, it is clear that we have four possible leadership styles. People-oriented authoritarian leader will be the one who makes most of decisions and takes responsibility, but in implementation of those decisions he/she relies on his/her influence to people and their interrelations. He values social structure of the organization very much, has high interpersonal skills and knows how to manage people. Another type of leader is one who applies the authoritarian style, but is taskoriented. This type of leader is also authoritarian and does not involve employees in decision-making, but is focused on labour, i.e. formal structure and realizes goals of the organization through structures, roles, procedures, orders, and the like. The third type of leader is the one who applies participative task-oriented style. This type of leader expects from employees to contribute to realization of organizational goals and believes that it is good for the organization that many of its members participate both in making and implementing decisions. This leader is oriented to work, formal structure and tasks. Therefore, he/she is not much interested in social structures and relationships because, according to him/her, they have to adapt to working structure. The fourth type of leader applies participative style and orientation to people in managing the organization. This type of leader involves employees in making and implementation of decisions, but at the same time relies on his influence on social structure of people and their interrelations.

\section{Research hypotetis}

In order to check the initial assumption about the influence of organizational culture on leadership we will generate and then test hypotheses that explain that influence. At the begininning, the hypothesis on whether there is such influence must be set up and tested. If organizational culture is the factor that affects leadership then the different types of organizational cultures will imply different styles of leadership. In this sense we set the initial hypothesis:

Hypothesis 1: Different leadership styles in the company correspond to different types of organizational cultures

Therefore, we note that different types of organizational cultures and leadership styles differ according to two dimensions of the same or similar content with two sexes each. This will ensure, during our empirical research, bringing in causal relationship certain types of organizational culture and leadership styles they imply, and thus test the initial hypothesis.

\section{Research methodology 4.1 Sample}

Empical research on influence of organizational culture on leadership was conducted in the period February - May 2012 on a sample of 324 employees in 16 companies in the Republic of Montenegro. A total of 400 questionnaires were distributed of which 76 questionnaires were not returned which makes response rate of $81 \%$. Companies are selected so as to be as diverse as possible: by ownership form, the business in which they operate, by age, size and by location. 8 of the 16 companies in the sample are state-owned, while privately owned companies represent the other half. The ratio of number of respondents in these companies was also approximately $50 \%$. The half of 16 companies deal with provision of service business with another 5 companies in the retail sector and 3 manufacturing companies.

Respondents were randomly chosen from the employees listed in company directories. Number of respondents per company ranged from 14 to 38 but most often the number of respondents in one company ranged from 20 to 30 . Respondents were of different ages given the fact that the majority of respondents, i.e. $37 \%$, was between 36 and 45 years old. When it comes to the level of education, the majority of respondents had secondary education degree, i.e. 159 respondents $(49,1 \%)$, while the number of those having university degree was significantly less, that is 30 respondents $(9,3 \%) .81 \%$ of 324 respondents were employees and only $19 \%$ were managers, enabling us to obtain a more realistic picture of organizational culture of the company. Gender structure of the sample was $54 \%$ male to $46 \%$ female.

\subsection{Variables and instruments}

The study of influence of organizational culture on job satisfaction involves operationalization of these two variables and their measurement. Therefore, the operationalization of organizational culture was performed through individual perception of respondents about the dominant type of organizational culture in their companies.

Since the organizational culture is operationalized using Handy's classification of types of organizational culture (1979), a questionnaire to diagnose the type of organizational culture developed by Handy based on earlier Harisson's classification of cultures (1972) was used accordingly. Respondents completed questionnaires anonymously. Since Handy's classification recognizes four types of organizational culture, the questionnaire consists of 15 questions with 4 answers offered to respondents which should be ranked from 1 to 4 in the way that the rank 1 should be given to the answer that is closest to a personal opinion of the respondent. Summing responses of each participant, the average ranks of four types of cultures were obtained, i.e. lower average rank means that the respondent perceived that this type of culture is more presented in his company. The lowest average rank given by the respondent to a certain type of culture means that the respondent perceived that this type of culture is dominant in his organization. The study first 
calculated the average ranks of each respondent given to each of four types of culture, and then constructed a variable called "culttype" that shows what type of culture each respondent perceived as a dominant one in his organization. The variable "culttype" has the values 1,2 , 3 and 4 with the value of 1 meaning that the individual respondent perceived power culture as the dominant type of culture in his company, the value of 2 means that he perceived that the dominant culture in his organization was the role culture, the value 3 implies that the dominant one was the task culture and the value of 4 means that he perceives people culture as the dominant type of culture in his company. "Culttype" variable was then used to analyse the influence of culture on job satisfaction.

Leadership style was operationalized through perception of respondents about the type of leader in his company and the manner in which he resolves problems in the company i.e. whether he does it through work or social structure and tasks.

\subsection{Research method}

Research results were statistically analysed with an adequate choice of statistical methods and depending on the type and distribution of data in order to provide an optimal model for consideration of influence, dependence and differences between the analysed data obtained in the research. For investigation of relationship between two discontinuous variables $\chi^{2}$ test was used. Statistical significance was defined at the level of probability of the null hypothesis of $p \leq 0,05$ to $p<0,0001$. Statistical processing and analysis were performed in the computer program SPSS ver. 20 (Statistical Package for the Social Sciences), a graphical and tabular presentation in Microsoft Office (Excel and Word).

\section{Research findings}

According to ranking of certain types of organizational culture, each respondent's perception as to what type of organizational culture his company belongs was determined. Of the total of 324 respondents, the largest number, i.e. 41 $\%$ of them, perceived that the power culture is the most presented in their companies, $32 \%$ perceived that it is the task culture, $22 \%$ opted for role culture and $5 \%$ for people culture.

Table 1Type of organizational culture

\begin{tabular}{|c|c|c|}
\hline Type of culture & $\begin{array}{l}\text { Number of } \\
\text { companies }\end{array}$ & $\begin{array}{c}\text { Structure of the } \\
\text { company }\end{array}$ \\
\hline Power culture & 133 & 41,0 \\
\hline Task culture & 104 & 32,1 \\
\hline Role culture & 72 & 22,2 \\
\hline People culture & 15 & 4,6 \\
\hline Total: & 324 & 100,0 \\
\hline
\end{tabular}

In this part of the study, we tested the influence of organizational culture on the choice of one of two leadership styles: authoritarian and participative. Depending on the degree to which the leader involves employees in the process of decision-making and their implementation, a leader can be authoritarian and participative. As the word itself says, the authoritarian leader relies on his authority and makes decisions independently without including employees. Participative leader makes decisions including employees in the process of decision-making and their implementation in the company.

Consequently, initial hypothesis is: Different leadership styles correspond to different types of organizational culture.

The results obtained have shown that there is a statistically significant relationship between leadership styles and types of organizational culture $\left(x^{2}=8,11 ; p=\right.$ $0,044)$. Therefore, different types of organizational culture imply different leadership styles. The leader in a particular organizational culture will choose the leadership style that fits best to the assumptions contained in that culture. Otherwise, he will not be accepted as a leader.

Power culture and the role culture are authoritarian cultures with uneven distribution of power, which means that power is concentrated, i.e. centralized at the top. The leader is expected to make decisions alone, without consulting his subordinates, so in case he tried to involve employees in decision-making, he would be understood as indecisive and incompetent. As our research has shown, authoritarian leadership style suits best to such cultures. Therefore, the results obtained show that in the role culture, the majority of respondents, i.e. 33 of them or $25,2 \%$, is of opinion that their leader applies authoritarian leadership style. In the power culture $45,8 \%$ of respondents believe that their leader applies authoritarian leadership style.

Task and people culture support are egalitarian cultures with balanced distribution of power. Thus, power is not concentrated only on the top, but it is evenly distributed within the company. In these cultures, the leader makes decisions with involvement of employees in the process of decision-making. In this sense, participative leadership style suits best to these cultures, which was also shown by the data obtained. In the task culture, $68 \%$ of respondents or $35,2 \%$ holds that their leader applies participative leadership style. In the power culture, 13 out of total of 15 respondents believe that their leader also applies participative leadership style. Therefore, the hypothesis of task culture and people culture imply participative leadership style. If the leader tried to apply authoritarian style, he would be seen as a dictator who does not respect its associates.

Hence, hypotheses about the relationship between organizational culture and leadership styles were fully confirmed. Based on the research we have shown that:

The role culture and power culture imply authoritarian leadership style.

Task culture and people culture imply participative leadership style.

$\chi^{2}=8,11 ; d f=3 ; p=0,044$.

Depending on the manner of solving problems in the company leaders may be oriented to people or tasks. Leaders oriented to people solve problems through working structure and tasks. Leaders oriented to tasks solve problems through social structure. In this regard, we distinguish between four types of leaders: authoritarian style oriented to people, authoritarian style oriented to tasks, participative style oriented to people and participative style oriented to tasks. 
$\chi^{2}=22,72 ; d f=3 ; p=0,000$.

The research has shown that there is a statistically significant relationship between the way in which directors solve problems in the company and the type of organizational culture $\left(\chi^{2}=22,72 ; p=0,000\right)$. As already mentioned, leaders can solve problems in the company through orientation to people (working structure) or through orientation to task (formal structure), so that different types of organizational culture imply different ways for solving problems in the company.

Table 2 Type of organizational culture * Types of leadership in the company

\begin{tabular}{|c|c|c|c|c|c|c|c|}
\hline \multirow{2}{*}{\multicolumn{3}{|c|}{ Types of leadership in the company }} & \multicolumn{4}{|c|}{ Type of organizational culture } & \multirow{3}{*}{$\begin{array}{c}\text { Total } \\
131\end{array}$} \\
\hline & & & \multirow{2}{*}{$\begin{array}{c}\begin{array}{c}\text { Role } \\
\text { culture }\end{array} \\
33\end{array}$} & \multirow{2}{*}{$\begin{array}{c}\begin{array}{c}\text { Power } \\
\text { culture }\end{array} \\
60 \\
\end{array}$} & \multirow{2}{*}{$\begin{array}{c}\begin{array}{c}\text { Task } \\
\text { culture }\end{array} \\
36 \\
\end{array}$} & \multirow{2}{*}{$\begin{array}{c}\begin{array}{c}\text { People } \\
\text { culture }\end{array} \\
2\end{array}$} & \\
\hline Which of the & authoritarion & Total & & & & & \\
\hline following types of & autnontartan & $\%$ & 25,2 & 45,8 & 27,5 & 1,5 & 100,0 \\
\hline leadership describes & narticinative & Total & 39 & 73 & 68 & 13 & 193 \\
\hline your director the best? & participative & $\%$ & 20,2 & 37,8 & 35,2 & 6,7 & 100,0 \\
\hline \multirow{2}{*}{\multicolumn{2}{|c|}{ Total }} & Total & 72 & 133 & 104 & 15 & 324 \\
\hline & & $\%$ & 22,2 & 41,0 & 32,1 & 4,6 & 100 \\
\hline
\end{tabular}

Table 3 Type of organizational culture * Orientation in solving problems

\begin{tabular}{|c|c|c|c|c|c|c|c|}
\hline \multirow{2}{*}{\multicolumn{3}{|c|}{ Orientation in solving problems }} & \multicolumn{4}{|c|}{ Type of organizational culture } & \multirow{3}{*}{$\begin{array}{r}\text { Tota } \\
87 \\
\end{array}$} \\
\hline & & & \multirow{2}{*}{$\begin{array}{c}\begin{array}{c}\text { Role } \\
\text { culture }\end{array} \\
25\end{array}$} & \multirow{2}{*}{$\begin{array}{c}\text { Power } \\
\text { culture } \\
19\end{array}$} & \multirow{2}{*}{$\begin{array}{c}\begin{array}{c}\text { Task } \\
\text { culture }\end{array} \\
41\end{array}$} & \multirow{2}{*}{$\begin{array}{c}\begin{array}{c}\text { People } \\
\text { culture }\end{array} \\
2\end{array}$} & \\
\hline \multirow{4}{*}{$\begin{array}{l}\text { When solving } \\
\text { problems a director } \\
\text { is oriented to: }\end{array}$} & \multirow{2}{*}{ people } & Total & & & & & \\
\hline & & $\%$ & 34,7 & 14,3 & 39,4 & 13,3 & 26,9 \\
\hline & \multirow{2}{*}{ task } & Total & 47 & 114 & 63 & 13 & 237 \\
\hline & & $\%$ & 65,3 & 85,7 & 60,6 & 86,7 & 73,1 \\
\hline \multirow{2}{*}{\multicolumn{2}{|c|}{ Total }} & Total & 72 & 133 & 104 & 15 & 324 \\
\hline & & $\%$ & 100,0 & 100,0 & 100,0 & 100,0 & 100 \\
\hline
\end{tabular}

Role culture is a bureaucratic culture where everything is oriented to work, i.e. formal structure. In these cultures everything is formalized and everything is done in accordance with formal division of labour in roles. In this culture a leader does not include employees in decision making and shaping of organizational action. He is more oriented towards formal structure of the organization (orders, procedures). We may conclude that in the role culture the most effective leaders would be the ones who use authoritarian style oriented to tasks, as our research has confirmed. Namely, in role culture, the majority of 72 respondents, i.e. 47 of them $(65,3 \%)$ believe that the leader in their company uses authoritarian style oriented to tasks when solving problems.

Therefore, the hypothesis that organizational culture determines the leadership style has been confirmed, since it has been proven that the role culture implies authoritarian style oriented to tasks.

The power culture treats an organization as a family, and a leader as father of the family. This culture is oriented to people and their interrelations in organizational action. In this culture leader regulates relationships through his influence on employees, i.e. through social structure. It is natural that the leader who uses authoritarian style of leadership oriented to people suits such culture best. This leader makes most of decisions alone and assumes responsibility, but in implementation of these decisions he relies on his influence to people and their interrelations. However, this study has not shown it. Only 19 out of 133 respondents $(14,3 \%)$ holds that their director is oriented to people when solving problems while greater number of respondents, i.e. 85 or $7 \%$ of them believe that the leader is nevertheless oriented to tasks when solving problems in the company. Therefore, the hypothesis that organizational culture affects the choice of leadership style has not been confirmed in this part, because it was not proven that the power culture implies authoritarian style oriented to people. The reason is that, due to characteristics of already mentioned Montenegrin national culture, the authoritarian leader, who solves problems through orientation to tasks, is certainly more popular, as the results obtained have shown.

In the task culture everything is subordinated to achieving goals and objectives of an organization through work, i.e. formal structure. Leader expects employees to participate in the process of decision-making and their implementation. $\mathrm{He}$ is not interested in interpersonal relationships since they have to be adapted to working environment. $\mathrm{He}$ is oriented only to formal structure and tasks. In such cultures only leaders who combine a participative leadership style oriented to tasks can be successful and effective. This has been confirmed by our research. In the task culture $60,6 \%$ of respondents believe that the leader in their company uses participative style oriented to tasks when solving problems. We conclude that the hypothesis about the influence of organizational culture on leadership has been confirmed in the part where the task culture implies a participative style oriented to tasks.

The people culture means that an organization is oriented to people and their needs and interests. The leader who applies participative style oriented to people suits best to such cultures. This type of leader involves employees in the process of decision-making and their implementation, but at the same time relies on his influence to people and their interrelations, i.e. social structure. However, our research did not show it. Namely, $86,7 \%$ of respondents in people culture believe that their director solves problems in the company through tasks, orders and procedures, and only $13,3 \%$ believes that their director relies on his influence to people and their interrelations, i.e. social structure when solving problems in the company. Therefore, the hypothesis 
that organizational culture determines leadership style has not been confirmed in the part that the people culture implies participative style oriented to people. This culture encompassed only 15 respondents, so it is disputable how valid the conclusions may be based on perception of such significantly small number of employees.

\section{Conclusion}

Empirical research presented in this paper has shown that organizational culture represents one of factors which determine internal life of a company. As such, it also affects leadership. Research results showed that there is a systematic and statistically significant connection between leadership styles and types of organizational culture in sampled companies.

The main conclusion of this paper would be that the organizational culture is a factor that affects choice of leadership style in the company, i.e. due to different content of values and norms, different types of organizational culture dictate different leadership styles. Thus, power culture and role culture are authoritarian cultures with balanced distribution of power and as such they imply authoritarian leadership style. Task culture and people culture are egalitarian cultures, i.e. cultures in which power is distributed unevenly and as such they imply participative leadership style. The above mentioned research confirmed both hypotheses. Further investigation confirmed that the role culture implies authoritarian style oriented to tasks and that the task culture implies participative style oriented to task. However, the hypothesis that the power culture implies authoritarian style oriented to people was not confirmed, the same as the hypothesis that people culture implies a participative style oriented to people.

What cannot be clearly seen from this study and what still needs to be explored is whether the organizational culture, in addition to direct has also indirect or moderating influence on leadership? This refers primarily to the possibility that organizational culture affects some of other leadership factors thus affecting leadership itself.

It is important to emphasize that this study has some limitations both in theoretical framework and in research methodology. Theoretical limitation of this paper is that the analysis of organizational culture was done from the standpoint of perception of employees about the dominant type of culture in their organization, and not the actual type of organizational culture present in the company. Also, the model used in the study is quite sparse. Namely, only the influence of two variables was explored in the paper, so the inclusion of some other variables would give a more accurate picture of influence of culture on leadership.

As regards methodological limitations the basic question is whether the sample was representative enough considering that there are very few organizations in which People culture dominates, i.e. how valid are conclusions based on a small number of respondents related to in this culture. Furthermore, when it comes to assessment of organizational culture it is important to point out that only the dominant type of organizational culture according to perception of respondents was taken into account, not other types present in that organization. Likewise, methodological limitation of this paper is that in research of relationship between culture and leadership numerous factors were not controlled that could have an impact on this relationship. The research controlled the following influence on the relationship between culture and leadership: age, gender, type of ownership. However, the influence of some potentially important factors such as company performance, type of organizational structure, size of a company was not controlled.

\section{References}

[1] Alavi, M.; Kayworth, T.R.; Leidner D.E. An Empirical Examination of the Influence of Organizational Culture on Knowledge Management Practices. // Journal of Management Information Systems. 22, 3(2005/6), pp. 191224.

[2] Alvesson, M. Understanding Organizational Culture. Sage, London, 2002. DOI: 10.4135/9781446280072

[3] Ashkanasy, C.; Wilderom, P. M.; Peterson, M. F. The Handbook of Organizational Culture and Climate. Sage, Thousand Oaks, California, 2001.

[4] Baird, K.; Harrison, G.; Reeve, R. The Culture of Australian Organizations and Its Relation with Strategy. // International Journal of Business Studies. 15, 1(2007), pp. $15-41$

[5] Balthazard, P.; Cooke, R. E.; Potrer, R. A. Dysfunctional Culture, dysfunctional organization: capturing the behavioral norms that form organizational culture and drive performance. // Journal of Managerial Psychology. 21, 8(2006), pp. 709-732. DOI: 10.1108/02683940610713253

[6] Berson, Y.; Oreg, S.; Dvir, T. CEO Values, Organizational Culture and Firm Outcomes. // Journal of Organizational Behavior. 29(2008), pp. 615-633. DOI: 10.1002/job.499

[7] Cameron, K. S.; Quinn, R. E. Diagnosing and changing organizational culture: The competing vales framework, $2^{\text {nd }}$ ed. Jossey-Bass, San Francisco, 2006.

[8] De Long, D. W.; Fahey; L. Diagnosing Cultural Barriers to Knowledge Management. // Academy of Management Executive. 14, 4(2000), pp. 113- 127.

[9] Deal, T.; Kennedy, A. Corporate cultures: the rites and rituals of corporate life. Addison Wesley, New York, 1982.

[10] Deem, J. M.; Barnes, B.; Segal, S.; Preziosi, R. 2010. The relationship of organizational culture to Balanced Scorecard effectiveness. // SAM Advanced Management Journal. 75, 4(2010), pp. 31-39

[11] Denison, D.R. Organizational culture and effectiveness: can American theory be applied in Russia? // Organization Science. 14, 6(2003), pp. 686-706. DOI: 10.1287/orsc. 14.6.686.24868

[12] Giberson, T. R.; Resick, C. J.; Dickson, M. W.; Mitchelson, J. K.; Randall, K. R.; Clark M. A. Leadership and Organizational Culture: Linking CEO Characteristics to Cultural Values. // Journal of Business Psychology. 24(2009), pp.123-137. DOI: 10.1007/s10869-009-9109-1

[13] Handy, C. Gods of management. Pan, London, 1979.

[14] Handy, C. Understanding organizations. Oxford University Press, New York, 1983.

[15] Henri, J. F. Organizational culture and performance measurement systems. // Accounting, Organizations and Society. 31(2006), pp. 77-103. DOI: 10.1016/j.aos.2004.10.003

[16] Klein, A. Corporate culture: its value as a resource for competitive advantage. // Journal of Business Strategy. 32, 2(2011), pp. 21-28. DOl: 10.1108/02756661111109743

[17] Martin, J. Organizational Culture: Mapping the Terrain. Sage, Newbury Park, California, 2002. DOI: 10.4135/9781483328478 
[18] Ranson, S.; Hinings, B.; Greenwood, R. The structuring of organizational structures. // Administrative Science Quarterly. 25, 1(1980), pp. 1-17. DOI: 10.2307/2392223

[19] Schein, E. Organizational Culture and Leadership. Sage, Thousand Oaks, California, 2004.

[20] Trompenaars, F. Riding waves of culture: understanding diversity in global business. McGeaw Hill, New York, 1994.

[21] Wilderom, C.; Glunk, U.; Maslowski, R. Organizational culture as a predictor of organizational performance. // In: Ashkanasy, N.; Wilderom, C.; Peterson, M. Handbook of Organizational Culture \& Climate. Sage, Thousand Oaks, California, 2000

[22] Wright, A. Culture and compensation - unpicking the intricate relationship between reward and organisational culture. // Thunderbird International Business Review. 52, 3(2010), pp. 189-202. DOI: 10.1002/tie.20324

[23] Yarbrough, L.; Morgan, N. A.; Vorhies, D. W. The impact of product market strategy-organizational culture fit on business performance. // Journal of the Academy of Marketing Science. 39, (2011), pp. 555-573. DOI: 10.1007/s11747-010-0238-x

\section{Authors' addresses}

Gordana Nikčević, M.Sc., PhD candidate

Faculty of Economics, University of Montenegro,

Jovana Tomaševića 37, 81000 Podgorica, Montenegro

E-mail: gogan@t-com.me 